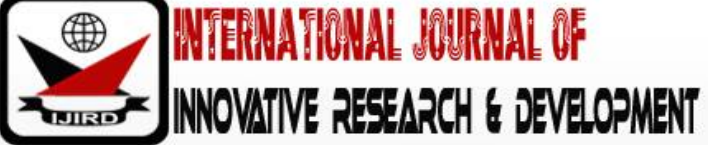

ISSN 2278 - 0211 (Online)

\section{Investigation of Operational Risk Management Quality and Operational Risk Losses: Evidence from Ghana}

\author{
Yushen Kong \\ Professor, School of Finance and economics, Jiangsu University, China \\ Samuel Asubonteng \\ Ph.D. Candidate, School of Finance and economics, Jiangsu University, China \\ Jean-Jacques Dominique Beraud \\ Master, School of Finance and economics, Jiangsu University, China
}

\begin{abstract}
;
This study documents the link between the quality of risk management practices and the operating losses of financial institutions in Ghana. Using detailed supervision data, we found that companies with lower risk management practices are higher and more volatile operating losses. We also provided evidence that the strength of risk management practices prior to the 2008-2009 financial crisis have an explanatory power. Losses during the crisis period. Our analysis provides new evidence of the importance of risk management practices to limit risk in financial institutions.
\end{abstract}

Keywords: Risk management, operation loss, financial institution

\section{Introduction}

According to Netter \& Poulson, (2003) Operational Risk (OP) is seen as a relatively new risk category noted within the risk management circle of a banking institution in the Basel Capital Accord. Operational Risk could be termed as the risk of loss as a result of process, people and internal failure or any other external influence that has a negative effect on the day-to-day business of the bank (Bessis, 2015). It is however noted that this risk could be found not only in the operations and functions of the bank but also in their products and services carried out to others. That is to say, every section or unit of department of the bank has no immunity to operational risk, being it finance, credit, treasury or information technology. Operational risk has been present in banking activities ever since banks were established however, it surfaced in the 1990s in the wake of financial institution failures by the likes of Daiwa bank in New York, Baring bank in London and Ihlas House in Turkey (Alexander, 2003). In the advanced countries, operational risk is highly prominent among the financial institutions as a result of high profile losses by the banks which could be associated with poor operational risk management. A clear case of example is the loss of (\$US1.4 billion) by the Barings Bank in 1995, (\$US691.2 million) by the Allied Irish Bank (AIB) in 2002 and the (\$A360 million) by the National Australia Bank (NAB) in 2004 (Etu-Mensah, 2011). These losses were huge, and brought severe effects to the institutions. To be more specific, financial losses from weak corporate governance are mostly contributed by people risk. It is explained that the bankruptcy of Barings Bank and the over 1 billion loss in Daiwa Bank were because of fraud by one person, while the huge loss by Ihlas Finance was due to mismanagement by a group of individuals. With respect to Daiwa bank, the low performance recorded after the 1997 Asian Financial crisis was as a result of system failure due to weak monitoring and controlling, particularly in the area of overseeing liquidity and market risk. Clearly, the losses could be linked to many factors as primary rogue and unethical behaviors and inadequate monitoring checks for Barings and Daiwa banks. Other reasons that could also be linked to these losses are weaknesses in the internal control mechanisms, ineffective regulatory checks, poor management and the behavior of the monitory authorities to the Ihlas Finance in the after the 1997 financial crises.

In Ghana, the Central Bank, in connection with the Bank of Ghana (BoG) revoked the license of operation for two banks by name UT and Capital banks, denying them the legal permission to operate as commercial banks in 2017 as a result of capital deficiency, poor management and weak corporate governance framework, which fall within the umbrella of operational risk (Addison, 2018). Effective operational risk management therefore lies at the core as a mitigation measure to arrest most of the common threats that seek to promote financial distress. This study is however conducted to access the effects of board composition on the control of operational events in commercial banks in Ghana for effective development of the financial institutions and as well contribute to shareholders' value.

The financial sector plays a crucial role in the build-up and development of every nation. For this matter it becomes very important for the sector to take active interest in monitoring the risks associated with their products and services. The traditional risk management practices have always been limited to ensuring the security of tangible assets presented in the organization financial statement. (African Economic Outlook, 2016). The banking industry has in recent times seen some evolutional changes in the business environment due to the growing concern of customer expectations, 
changes in compliance regulations, rivalry competition and fast pace of technological innovations. This situation has influenced the increased chances of committing errors and failures in operations. That is to say, the process through which the banks conduct their businesses are in one way or the other challenged by operational risk. These risks constitute a significant threat to the growth and even the survival of the business, and therefore need to be mitigated. Most commercial banks in Ghana have over the past witnessed the resulting effects of operational risks due to failed internal processes of which huge sums of money is lost and other banks having their license revoked by the central bank and bank of Ghana. Many banking experts have suggested the need to equip banking staff with modern training, since they believe most of the causes of such huge losses are as a result of inadequate training of staff (Ware, 2015). The commonly identified operational risk in the Ghanaian banking industry are; servicing of cloned cheques, pin code theft of Automated Teller Machine (ATM), cheques incorrectly cleared and paid, cheques honored wrongfully and other important service and product defects.

While many banks in the world have severely suffered huge losses which are attributed to poor operational risk management as in the case of the collapse of Lehman Brothers and Freddie Mac of the United States in the year 2008, and the bailout of the American International Group (AIG) by the Federal Reserve of America which saved AIG from collapsing, Barings Bank in 1995 (\$US1.4 billion), Allied Irish Banks (AIB) in 2002 (\$US691.2 million) and National Australia Banks (NAB) in 2004 (\$A360 million), most Ghanaian banks in recent years have also not had their peace due to this same poor operational risk management. The take-over of Capital Bank and UT Bank by Ghana Commercial Bank among others by the order of Central Bank and Bank of Ghana has shifted the attention of many analysts and regulators towards operational risk management. It is of no surprise that many topical issues for discussion within the banking industry for the past two years seem to have operational risk management as a key interest of the major stake holders. Operational risk, as quite different from market and credit risk are undoubtedly inherent in the product and services the banks offer to the public and appear to be complex, dynamic and difficult to estimate (Jorion 2005). This is not to assume that operational risks are too complex that they could not be mitigated, since a framework with timelines has been offered by the Basel Committee on Banking Supervision (BCBS) to manage operational risk in order to promote the growth and expansion of the banking industry. However, the recent crack of the whip by the Central Bank and Bank of Ghana on Capital Bank and UT Bank, which were believed to have suffered losses due to poor operational risk management practices. In August 2017, the Bank of Ghana finally gave GCB Bank the green light to acquire both UT Bank and Capital Bank. In August 2018, the Bank of Ghana announced the creation of Consolidated Bank to take over 5 struggling local banks. The five banks are Beige Bank, Sovereign Bank, Construction Bank, the Royal Bank and Unibank.

\section{Literature Review}

The Basel Committee on Banking Supervision (BCBS) under the Basel I capital accord was formed in July 1988 by the government of the United States of America but was operational in 1992 (Getter, 2011). It was formed with the objective of stimulating reliable, safety and sound standard and at the same time ensuring a fair basis of competition in the banking industry. The Basel I Capital Accord clearly defines the capital requirements for the banks to maintain as a form of regulatory measure. The Basel Capital Accord introduced some regulatory frameworks which includes; the Tier one capital risk-weighted asset ratio which aims to task the financial institutions to hold enough capital reserves in order to meet the minimum capital required asset-ratio that could cushion the institution against vulnerabilities or unexpected default of loans by the customers. The Tier two aspect deals with the allowance for loan and lease losses adjusted quarterly as per the default. The Basel I capital accord also deals with stress testing which aims at finding out the resilience of the banks to withstand losses as a result of excess recession and systematic risk.

The Basel II does not limit itself to only operational risk concerns but also highlights three pillars. Pillar one touches on the need to improve regulatory capital requirements (Standardized Approach). Pillar two touches on a supervisory review process (Foundation Internal Rating Based Approach), while pillar three touches on enhanced disclosure for transparency and market discipline (Internal ratings based approach) (Dugan, 2011). In the United States, the Federal Banking Agencies did not adopt the implementation of the regulation under Basel II immediately but waited until April 2008. Unlike the other European nations, the US adopted only parts of Basel II principles for the largest banks (Getter, 2014). Dugan (201) explained that this decision was applicable due to the fact that the largest banks had the resources and capability to handle complex approaches, and in as much the smaller banks lack the resources and capability it was concluded that complex approach will ever remain a challenge to them. Similarly, the Federal Banking Agencies were of the conviction that since the smaller banks were not competing globally, the adoption would not reflect in improving capital requirements. Finally, the third pillar touches on the requirement to enhanced disclosure for transparency and market discipline (Internal Rating Based Approach).

Operational risk has been identified as a different risk category from market and credit risk by Basel II since 2001 (Chernobai, Rachev \& Fabozzi, 2008). Though Basel Committee on Banking Supervision has come out with good approaches for the measurement of operational risk, their level of sophistication differ from bank-to-bank. This could be attributed to the fact that operational risk is considered the most complicated risk type in relation to risk identification, quantification and mitigation. Operational risk is uniquely dynamic and is influenced by many events like international business processes, regulatory land scape, customer preference, business growth and other external factors. The concept of risk management has never assumed a simple function for banks and those who fail to handle it well always have huge prices to pay. Currently, the awareness and reliance on regulatory compliance and risk management have become deeper, the neglect of which shall have a significant impact on the bank's ability to thrive competitively (Kay, 2009). The risk function has taken a different turn from a number crunching function to a dynamic business enabler, with risks emanating from complex products, multiple channels, diverse workforce, diversified operations and regulatory compliance at both 
international and regional levels. This therefore calls for the need to place emphasis on proactive risk management rather than event-based response. The open truth is that banks consider risk management as their natural business, as such a comparative view of the operational risk management system between banks and the other economic sectors attests that the banks have more developed and refined risk management systems.

Activities to be performed by people have inherent risk in them, and the more complex the activity looks the higher the risk involved. Internally, it is common to have cases of incorrect processing, wrong input of data into the system, omissions and other clerical mistakes and errors especially when staff members are inexperience, under pressure or working under stress condition. Aside those staff members who with a wrong intent to defraud or cause injury to the organization, most of the situations like errors, mistakes and other omissions and wrong inputs are not committed with the intent for personal gains (Cornalba \& Giudici, 2004). In an instances where investigation prove that too many operational risk event occurred by employees were as a result of mistakes and errors but nothing like a deliberate action to wound the organization or a third party, it an indication that the employees need more training programs to upgrade their skills to better handle professional duties devoid of negligence. The difficult challenge to deal with is how to convincingly determine whether action of employees was a fraud or a mistake as most of people risk could be a little complicated. Employees must also be given fair treatment so far as the labor laws and contracts are concerned, especially those relating to staff annual leave. This become very important as too much stress could result in too many errors and mistakes while on the job (Cania, 2014). Another management strategy that could curb error and mistakes is the strategy of matching the skills of the employees to the right job description. The naked fact is that people with the right skills for the right job may be more competent and may not waste time on delivery.

The competitive nature of the banking industry demands that the firms position themselves well to address the sophisticated user wants, regulatory requirements, market adjustment and internal records management (Hitt etal, 2012). Technological system failure and breakdowns may cause many negative impact and cost to the firm, from an unauthorized access to confidential data and statistics to reputational concerns (Goldstein etal, 2011). It is therefore important for management to have a robust system in place and be proactive enough to identify and control threats in order to reduce risk related to security breaches. Information system audit is another measure firms can adopt. It is a complex function executed to check the information system and to give the right opinion on the compatibility to ensure that firms use their systems to satisfy the organizational objectives. Information system auditor plays a leading role by reviewing all security over the facility and to safeguard its protection from possible threats.

According to Harmon \& Trends (2010), the reliance on Business Process Management (BPM) could go a far way to minimize operational risk in the organization. This is a discipline designed to discover, execute and control automated and non-automated business enterprise procedures to achieve stated objectives expressed by the employers of the organization. Business Process Management makes it possible for the organization to align routine processes to the organizational methods. Business processes are handled by people and in some cases robots. However, Human beings are the most priceless assets of any agency and as such need to receive the right type of training in order to handle business processes excellently. Unfortunately, enough, many financial organizations by whatever reasons employ people who lack the necessary experience and qualifications to professionally execute the assigned responsibilities (Ward, 2016). Such inexperienced people are not far from committing serious blunders as to how to smartly and professionally handle the process, which could result in a chain of operational losses. Governance is identified a major item of procedure management, and as such good governance could enhance centralized coordination in the business process and also in the management of BPM competencies.

\section{Methodology}

We conducted a regression analysis of the network output as a mean of determining the generic coefficient of claim. Neural prediction to determine the best optimum sealing to sustain banks for crashing. We selected in all 30 banks each from each region. In 2017, The BoG recorded over 50 Banks under its jurisdiction. The selection consisted of the top 10 banks with the highest operational risk per district, per region under BoG and the lowest 10 lowest rating banks per district. A population model for a multiple linear regression model that relates a y-variable to $\mathrm{p}-1 \mathrm{x}$-variables is written as; $\mathrm{y}=\beta_{\mathrm{o}}+\beta_{1} \mathrm{x}_{\mathrm{i} 1}+\beta_{2} \mathrm{x}_{\mathrm{i} 2}+\cdots+\beta_{\mathrm{n}} \mathrm{x}_{\mathrm{in}}+\varepsilon_{\mathrm{i}}$

We assume that the $\varepsilon_{\mathrm{i}}$ have a normal distribution with mean 0 and constant variance $\sigma^{2}$

These are the same assumptions that we used in simple regression with one $\mathrm{x}$-variable.

The subscript i refers to the it individual or unit in the population. In the notation for the $\mathrm{x}$-variables, the subscript following i simply denotes which $\mathrm{x}$-variable it is.

The word "linear" in "multiple linear regression" refers to the fact that the model is linear in the parameters, $\beta_{\mathrm{o}}, \beta_{1}, \beta_{2}, \ldots ., \beta_{\mathrm{n}}$. This simply means that each parameter multiplies an $\mathrm{x}$-variable, while the regression function is a sum of these "parameter times $\mathrm{x}$-variable" terms. Each $\mathrm{x}$-variable can be a predictor variable or a transformation of predictor variables (such as the square of a predictor variable or two predictor variables multiplied together). Allowing non-linear transformation of predictor variables like this enables the multiple linear regression model to represent non-linear relationships between the response variable and the predictor variables.

The estimates of the $\beta$ coefficients are the values that minimize the sum of squared errors for the sample. The exact formula for this is given in the next section on matrix notation.

The letter $b$ is used to represent a sample estimate of $a \beta$ coefficient. Thus $b_{0}$ is the sample estimate of $\beta_{0}, b_{1}$ is the sample estimate of $\beta_{1}$, and so on. 
$\mathrm{MSE}=\frac{\mathrm{SSE}}{\mathrm{n}-\mathrm{p}}$, estimates $\sigma^{2}$, the variance of the errors. In the formula, $n=$ sample size, $p=$ number of $\beta$ coefficients in the model (including the intercept) and SSE $=$ sum of squared errors. Notice that for simple linear regression $p=2$. Thus, we get the formula for MSE that we introduced in that context of one predictor.

\section{Analysis}

This study used a supervisory operational loss data reported by BoG in accordance with the global standard report form. The Federal Reserve system under the BoG collects such operational loss data for the assessments of capital and also test for various banks operation under the BoG. Per the universal Banking Law, we have various types of loss defined as:

IF: Internal Fraud which is defined as a type of fraud that is committed by an individual against an organization or a misappropriation of property.

EF: External Fraud which is defined as a risk of unexpected financial, material or reputational loss as a result of fraudulent actions of persons external to the firm.

EPWS: Employment Practices and workplace Safety defined as an act of inconsistent with employments, health or safety laws.

DPA: Damage to Physical Assets which is unintentional or negligent failure to meet a professional obligation to specific clients for example natural disasters or event

EDPM: Execution, Delivery and process management which is a failure transaction processing or process management from relation with trade counterparties and vendors.

\begin{tabular}{|c|c|c|c|c|}
\hline & Mean & SD & P5 & P95 \\
\hline Op Loss & 0.243 & 0.738 & 0.01 & 0.886 \\
\hline Op Loss SD & 0.286 & 0.655 & 0.008 & 1.383 \\
\hline Risk Management & 2.268 & 0.477 & 2 & 3 \\
\hline Ln (Assets) & 12.223 & 1.214 & 10.85 & 14.593 \\
\hline Int to Nonint Inccm & 1.978 & 7.044 & 0.342 & 4.414 \\
\hline Leverage & 0.899 & 0.027 & 0.845 & 0.936 \\
\hline Tier 1 Capital & 0.111 & 0.026 & 0.07 & 0.158 \\
\hline Loan Losses & 0.024 & 0.019 & 0.002 & 0.067 \\
\hline Complex & 0.232 & 0.423 & 0 & 1.000 \\
\hline Processing & 0.168 & 0.473 & 0 & 1.000 \\
\hline Foreign & 0.178 & 0.392 & 0 & 1.000 \\
\hline Financial Crisis & 0.266 & 0.442 & 0 & 1.000 \\
\hline
\end{tabular}

Table 1: Summary Statistics

This table above displays the descriptive statistics of our data. The sample is composed of 1,008 quarterly observations of operational risk losses incurred by 30 major financial institutions during the period 2000-2013. Operational losses on losses incurred by BOG in a given calendar quarter, relative to BOG's total assets, multiplied by 1,000. Loss of op. Pd. measures the volatility of quarterly operating losses and is calculated as a standard deviation of operating loss using the previous float's quadruple float window. 5, with higher values. Ln (Asset) is the natural transformation of all Banks activities. Int-to-Nonint includes the relationship between Banks interest income and noninterest income. products. Level 1 Capital is a Tier 1 capital of BOG. Loss-bearing loan percentage of non-performing loans from BHC (accumulated over 90 days or more not earned) compared to total loans. Variables of complex indicators, processing and tracking used by the Federal Reserve to acquire the BHC group with similar operational risk characteristics. Specifically, Complex acquires complex and systemically important institutions. Processing institutions focus on specific banking services, such as investment management, asset and fund management and fiduciary services. Foreign financial corporation's represent an indicative variable equal to 1 during the period (2008-2011) and 0 otherwise

\subsection{Pair Wise Correlations and Univariate Sorts}

As a first step in uncovering the relation between the intensity of operational losses and risk management quality at financial institutions, we start with a simple correlation analysis. Table 2, Panel A reports pair wise correlation coefficients between Risk Management and Operational Loss Notably, the correlation between the risk management quality variable and operation allosses is $6 \%$, suggesting that banks with worse risk management practices experience higher operational losses per Ghana Cedis of assets. The correlation coefficient is statistically significant at the $10 \%$ level.

We then show similar results in a portfolio analysis setting. Specifically, we group bank-quarter observations into two buckets: one group with relatively stronger risk management quality as represented by "low "Risk Management (defined as Risk Mgmtless than 3) and one group with relatively weaker risk management quality represented by "high "Risk Management(defined asRisk Mgmtgreater than or equal to 3). Further, we calculate averages of Operational Loss for each group and calculate the mean difference across them. Table 2, Panel B presents the results. Confirming the evidence from Panel A, BHCs with stronger risk management practices experience lower operational losses per Ghana Cedis of assets than BHCs with weaker risk management. The difference in the group means is again statistically significant at 
the10\% level. We next turn to a more rigorous multivariate analysis of the relation between riskmanagement quality and operational losses at financial institutions.

\begin{tabular}{|c|c|c|c|c|}
\hline \multicolumn{5}{|c|}{ Panel A: Correlation } \\
\hline & & Op Loss & Risk & \\
\hline Variables & Op Loss & SD & Mgmt & \\
\hline Op Loss & 1.000 & & & \\
\hline Op Loss SD & 0.493 & 1.000 & & \\
\hline Risk Mgmt & $(0.000)$ & & & \\
\hline & 0.060 & 0.079 & 1.000 & \\
\hline Paanel B: sorts & $0.059)$ & $(0.012)$ & & $\mathrm{p}$-Value \\
\hline & & & & 0.098 \\
\hline Op Loss & Low & High & Low-High & 0.030 \\
\hline Op Loss SD & 0.217 & 0.298 & -0.081 & \\
\hline
\end{tabular}

Table 2: Correlations and Univariate Sort

Our next set of results employ multivariate regressions, which better enable us to control Risk for specific factors in examining the association between operational losses and risk management quality. We follow other operational risk studies (e.g., Cope et al.2012; Dahenand Dionne2010; Naetal.2006) and use ordinary least squares (OLS) regressions to model operational risk losses. In particular, we use the following specifications:

Op Loss i,t $=\beta_{0}+\beta_{1}$ Risk Mgmt $_{i, t}+\beta_{2} \operatorname{Crr}_{i, t}+\varepsilon_{i, t}$

Where I represent the Banks under BoG, and t represent the time periods (quarters). Op Loss i.t $_{\text {, }}$, represent the proportion of operational losses of total asset recorded by BoG i during quarter $t$. Risk Mgmt $_{i, t}$ is defined as the risk management rating assigned by the BoG in the a calendar year preceding quarter $\mathrm{t}$. $\mathrm{Ctrl}_{\mathrm{i}, \mathrm{t}}$ represent a control vector of variables which is comprised of the size of the firm, revenue composition.

\begin{tabular}{|c|c|c|}
\hline & $\mathbf{( 1 )}$ & $\begin{array}{c}\mathbf{( 2 )} \\
\text { Op Loss } \\
\text { Median }\end{array}$ \\
\hline Op Loss & $0.019^{* *}$ \\
& $\mathbf{0 L S}$ & $(0.017)$ \\
\hline Lnsk Mgmt & $0.070^{* *}$ & $0.024^{* *}$ \\
& $(0.033)$ & $0.000)$ \\
\hline Int-to-Nonint Incm & $0.078^{* *}$ & $-0.009^{* *}$ \\
& $(0.009)$ & $(0.000)$ \\
\hline Leverage & -0002 & 0.042 \\
& $(0.427)$ & $0.774)$ \\
\hline Tier 1 Capital & 1.075 & -0.033 \\
& $(0.205)$ & $(0.828)$ \\
\hline Loan Losses & -0.694 & $0.793^{* * *}$ \\
& $(0.667)$ & $0.000)$ \\
\hline Complex & 0.915 & 0.000 \\
& $(0.6260$ & $(0.993)$ \\
\hline Processing & 0.126 & $0.087 * * *$ \\
& $(0.167)$ & $0.000)$ \\
\hline Foreign & $0.220 * * *$ & 0.004 \\
& $(0.005)$ & $0.730)$ \\
\hline Financial Crisis & $0.096^{*}$ & -0.004 \\
& $(0.054)$ & $(0.689)$ \\
\hline Observations & 0.120 & 1009 \\
\hline Adjusted R & $(0.285)$ & \\
\hline
\end{tabular}

Table 3: Risk Management Quality and Operational Risk Losses $* \mathrm{P}<0.10, * * \mathrm{P}<0.05, * * * \mathrm{P}<0.01$

The table reports coefficients from OLS and Median regression of operational risk losses on risk management quarterly and control Variables. The p-values are presented in parentheses. It revealed that the processing and Loan Losses were significant at $\alpha$ level of 0.01 which contribute to the Operation Loss. However at $\alpha$ equal to 0.05

\section{Conclusion}

In this article, we investigated the relationship between the quality of risk management and operating losses in Ghana's leading financial institutions. We use two sets of monitoring data to test our hypotheses. First, we used a unique and rich set of data to monitor the operational losses of the 30 largest bank holdings with total assets exceeding 50 billion 
GHC, submitted to the Federal Reserve for stress tests. We integrated this data with risk management evaluations derived from regulatory reviews that evaluate the ability of BoG to identify, measure, monitor and control risks.

We found that, on average, bank holding companies with weak risk management practices experience greater and more volatile operating losses. We also showed that bank holdings with a strengthened risk management function before the start of the financial crisis suffered less operational losses during and after the financial crisis. In addition to contributing to the literature on the value of risk management practices and on banking risks and performance, our study has important political implications. Our results suggested that regulators and banking organizations should analyze operational losses together with risk management practices. More specifically, the conclusions of this document indicate that solid risk management functions can reduce exposure to operational risk and potentially improve the value of the asset, even in periods of economic difficulty.

\section{Reference}

i. Alexander, C (2003). Operational risk: regulation, analysis and management. New Jersey: Pearson Education.

ii. African economic outlook. (2016). Education \& Skills Mismatch: Young People Need More Comprehensive Education That Responds To Labour Market Needs. . African economic outlook.

iii. Netter, J. M., \& Poulsen, A. B. (2003). Operational risk in financial service providers and the proposed Basel capital accord: an overview. In Advances in Financial Economics (pp. 147-171). Emerald Group Publishing Limited.

iv. Cania, L. (2014). The Impact of Strategic Human Resource Management on Organizational Performance. Economia. Seria Management, 7(2), 373-384.

v. Cornalba, C., \& Giudici, P. (2004). Statistical models for operational risk management). Physical A: Statistical Mechanics and its applications, 338(1), 166-172.

vi. Bessis, J. (2015). Risk management in banking. John Wiley \& Sons.

vii. Dugan, J. (2011). US Implementationof Basel II: Final Rules Issued, But No Supervisory Approvals to Date. Washington, DC: European Parliament.

viii. Etu-Menson, F. (2011). Operational Risk Management in the Banking Industry of Ghana.

ix. Getter, D. (2014). U.S. Implementation of the Basel Capital Regulatory Framework.

x. Washington, DC: Congressional Research Service.

xi. Goldstein, J., Chernobai, A., \& Benaroch, M. (2011). An event study analysis of the economic impact of IT operational risk and its subcategories. Journal of the Association for Information Systems, 12(9), 606.

xii. Hitt, M. A., Ireland, R. D., \& Hoskisson, R. E. (2012). Strategic management cases: competitiveness and globalization. Cengage Learning.

xiii. Harmon, P., \& Trends, B. P. (2010). Business process change: A guide for business managers and

xiv. BPM and Six Sigma professionals. Elsevier.

xv. Ward, J. (2016). Keeping the family business healthy: How to plan for continuing growth, profitability, and family leadership. Springer.

xvi. Sadgrove, K. (2016). The complete guide to business risk management. Routledge.

xvii. Birch, D. G., \& Parulava, S. (2017). Ambient Accountability: Shared Ledger Technology and Radical Transparency for Next Generation Digital Financial Services. In Handbook of Blockchain, Digital Finance, and Inclusion, Volume 1 (pp. 375-387).

xviii. Breen, S., Hancock, J., Cosnett, J., \& Rose, A. (2017). MISHCON DE REYA BETTING AND GAMING CYBER BREAKFAST: CYBERATTACKS, DATA PROTECTION, AND FRAUD IN THE BETTING AND GAMING INDUSTRY. Gaming Law Review, 21(9), 684-693.

xix. Pavlou, P. A., \& Gefen, D. (2004). Building effective online marketplaces with institution-based trust. Information systems research, 15(1), 37-59.

xx. Johnson, K. N. (2015). Managing cyber risks. Ga. L. Rev., 50, 547.

xxi. Kshetri, N. (2010). The global cybercrime industry: economic, institutional and strategic perspectives. Springer Science \& Business Media.

xxii. Jun, M., \& Cai, S. (2001). The key determinants of internet banking service quality: a content analysis. International journal of bank marketing, 19(7), 276-291.

xxiii. Barry Johnston, R., \& Nedelescu, O. M. (2006). The impact of terrorism on financial markets. Journal of Financial Crime, 13(1), 7-25.

xxiv. Ugorji, B. (2017). Combating terrorism: a literature review. International Center for Ethno-Religious Mediation.

xxv. Chernobai, A. S., Rachev, S. T., \& Fabozzi, F. J. (2008). Operational risk: a guide to Basel II capital requirements, models, and analysis (Vol. 180). John Wiley \& Sons.

xxvi. Kay, J. A. (2009). Narrow Banking: The reform of banking regulation.

xxvii. Baud, C., \& Chiapello, E. (2017). Understanding the disciplinary aspects of neoliberal regulations: The case of credit-risk regulation under the Basel Accords. Critical Perspectives on Accounting, 46, 3-23.

xxviii. Bhasin, M. L. (2015). Menace of frauds in the Indian banking industry: an empirical study.

xxix. Osei, A. M., Seth, A., \& John, A. (2015). CUSTOMERS'PREFERENCE IN SERVICE DELIVERY, AN ASSESSMENT OF TAM AND IDT ON THE MEANS-END THEORY IN THE BANKING INDUSTRY: A CASE OF GHANA COMMERCIAL BANK Ltd IN GHANA. European Journal of Business andSocial Sciences, 3(11), 79-100.

xxx. Dzorgbo, D. B. S. (2017). Ghana in search of development: The challenge of governance, economic management and institution building. Routledge. 
xxxi. Adams, K., Debrah, Y. A., Williams, K., \& Mmieh, F. (2015). Why on earth should foreign banks invest in Africa's financial services sector? Evidence from financial multinationals in Ghana. Thunderbird International Business Review, 57(6), 445-462.

xxxii. Killick, T. (2010). Development economics in action second edition: a study of economic policies in Ghana. Routledge.

xxxiii. Kyeremeh, G. A. (2017). An assessment of credit delivery practices of microfinance institutions in Ghana, a case of Sinapi Aba Savings and Loans Ltd (Doctoral dissertation)

xxxiv. Antwi-Asare, T. O., \& Addison, E. K. Y. (2000). Financial sector reforms and bank performance in Ghana. London: Overseas Development Institute.

xxxv. Law, J. (2018). A Dictionary of Finance and Banking. Oxford University Press.

xxxvi. Geppert, J. P. (2016). Relationship of embezzlement and the economic condition in the United States economy (Doctoral dissertation, Capella University).

xxxvii. Tripe, D. (2000). Pricing operational risk. In 13th Australasian Finance and Banking Conference, Sydney, December

xxxviii. Allen, F., \& Santomero, A. M. (1997). The theory of financial intermediation. Journal of Banking \& Finance, 21(1112), 1461-1485.

xxxix. Hopkin, P. (2018). Fundamentals of risk management: understanding, evaluating and implementing effective risk management. Kogan Page Publishers.

xl. McNeil, A. J., Frey, R., \& Embrechts, P. (2015). Quantitative Risk Management: Concepts, Techniques and Toolsrevised edition. Princeton university press.

xli. Asare-Bekoe, K. M. (2010). A Risk-Based Assessment of Ecobank Ghana Limited (Doctoral dissertation, Master's Thesis, Copenhagen Business School).

xlii. Opoku-Adarkwa, R. (2011). Risk management and bank performance: a case study of First Atlantic Merchant Bank Ghana Limited (FAMBL) (Doctoral dissertation).

xliii. Koomson, A. (2011). Operational risk management and competitive advantage in the Ghanaian banking industry (Doctoral dissertation).

xliv. Yin, R. K. (2011). Applications of case study research. Sage.

xlv. Amaratunga, D., Baldry, D., Sarshar, M., \& Newton, R. (2002). Quantitative and qualitative research in the built environment: application of "mixed" research approach. Work study, 51(1), 17-31.

xlvi. Norušis, M. J. (2006). SPSS 14.0 guide to data analysis. Upper Saddle River, NJ: Prentice Hall.

xlvii. Osterwalder, A., \& Pigneur, Y. (2010). Business model generation: a handbook for visionaries, game changers, and challengers. John Wiley \& Sons.

xlviii. Taleb, N. N. (2012). Antifragile: Things that gain from disorder (Vol. 3). Random House Incorporated.

xlix. Rime, B. (2001). Capital requirements and bank behaviour: Empirical evidence for Switzerland. Journal of Banking \& Finance, 25(4), 789-805.

1. Diamond, D. W., \& Rajan, R. G. (2001). Liquidity risk, liquidity creation, and financial fragility: A theory of banking. Journal of political Economy, 109(2), 287-327.

li. Bainbridge, S. M. (2002). Director primacy: The means and ends of corporate governance. Nw. UL Rev., 97, 547. 